\title{
ETNOGRAFIA MYŚLI POTOCZNE] W DZIEDZINIE POZAAKADEMICKICH RELACJI Z PRZESZŁOŚCIA. MYŚL POTOCZNA JAKO PRZEDMIOT BADAŃ HISTORII HISTORIOGRAFII
}

Wojciech PIASEK

\section{ABSTRACT}

ETHNOGRAPHY OF COMMON SENSE IN THE FIELD OF NON-ACADEMIC RELATIONS WITH THE PAST. COMMON SENSE AS THE SUBJECT OF RESEARCH INTO THE HISTORY OF HISTORIOGRAPHY

By distancing ourselves from the previous ways of thinking about non-academic forms of history within history of historiography and methodology of history, I suggest using cultural anthropology in the research. In my opinion that its traditional field of study, e.g. the common sense, remains closely related to the study of history of historiography and methodology of history on non- academic forms of history.

\section{KEYWORDS:}

non-academic history, common sense, popular culture, cultural anthropology, ethnography of historical thought 
„Jeżeli interpretacja antropologiczna jest rodzajem spojrzenia, to mniej istotne wydaje się być to, jakiej profesji jest patrzący, niż to, jak widzi" (Cz. Robotycki, Etnografia wobec kultury współczesnej, Kraków 1992)

Rafał Stobiecki w swoim artykule Jakiej historii historiografii nam potrzeba? wskazuje na konieczność zmian historii historiografii. Niezbędność rewizji tożsamości dyscyplinarnej uzasadnia sytuacją współczesnej historiografii. Należy zgodzić się zarówno z jego diagnozą stanu historiografii, jak i uznać propozycję kierunku, w jakim w nowym kulturowym kontekście może iść historia historiografii . Mam jednak wątpliwości co do drogi jaką historia historiografii powinna obrać, realizując wyznaczony cel.

Zdaniem Stobieckiego:

na naszych oczach dokonuje się rozpad dotychczas w miarę jednolitego wzorca nauki historycznej. Widoczny staje się podział na historiografię konwencjonalną - akademicką i niekonwencjonalną, swego rodzaju, używając określenia Michela Foucaulta - „przeciw-historię”. Współczesność czyni równoprawnymi daleko odmienne od siebie narracje o przeszłości, wiedza o historii poddawana jest procesowi instrumentalizacji, nie zwraca się uwagi na obowiązujące wcześniej reguly metodologiczne. $W$ tej optyce zasadne staje się pytanie o to, czym jest i chce być dzisiaj historia historiografii? Oba wspomniane czynniki, a także szereg innych okoliczności, mają różny wpływ na współczesny status historii historiografii. Tworzą zarówno szanse, jak i zagrożenia dla będącej przedmiotem moich uwag dyscypliny ${ }^{2}$

W innym miejscu czytamy:

Marginalizacja akademickiej historiografii oznacza także marginalizację tradycyjnego przedmiotu badań historii historiografii. Dlatego jest dla mnie czymś oczywistym, że musi ona, chcąc nie chcąc, reagować na zmiany w sposobie rozumienia i praktycznego użytkowania owej wiedzy w społeczeństwie. [...] Nie ma powrotu do historii historiografii, której przedmiotem zainteresowania była przede wszystkim, akademicka, profesjonalna refleksja nad historią; [... W Winna ona otwierać się na inne, nowe, pozaakademickie formy refleksji nad przeszłością ${ }^{3}$.

Niewątpliwie dzisiejsza relacja z przeszłością jest spluralizowana. Dotyczy to nie tylko dyskursu akademickiego, przejawia się także w fakcie dojścia do głosu pozaakademickich form tej relacji. Trafne jest także stwierdzenie Stobieckiego,

R. Stobiecki, Jakiej historii historiografii nam potrzeba?, „Kultura i Historia”, 2014, nr 25 : http:/ www kulturaihistoria.umcs.lublin.pl/archives/5239 [dostęp: 23-04-2015]. Zob. także: Tenże, Historyk i jego rola we wspótczesnym świecie, [w:] Gra i konieczność. Zbiór rozpraw z historii historiografii i filozofii historii, red. G. A. Dominiak, J. Ostoja -Zagórski, W. Wrzosek, Bydgoszcz 2005, s. 49-60.

2 Tamże.

3 Tamże. 
iż w przeciwieństwie do sytuacji jaka miała miejsce jeszcze kilkanaście lat temu, w pozaakademickich formach relacji z przeszłości niekoniecznie dąży się do tego, by były one zgodne z tym, co na temat przeszłości piszą historycy. Nie rozpatrywałbym jednak stanu współczesnej kultury jako szans i zagrożeń dla historii historiografii. Daleki jestem od tego, by nauce i historii akademickiej wyznaczać specjalne miejsce w społeczeństwie wspierając się przy tym na ideologii scjentyzmu4 $u^{4}$.

Nie widzę potrzeby szerszej prezentacji mojego poglądu na naukę i jej rolę, w tym historii historiografii i metodologii historii, ale jest on o wiele skromniejszy i wynika z przyjęcia antropologicznej perspektywy ${ }^{5}$. Chcę jedynie podkreślić, iż od tego, jak myślimy o tym, czym jest nauka, na ile widzimy ją jako jedną z praktyk kulturowych, zależy, jak będziemy postrzegać nieakademickie formy relacji z przeszłością i w konsekwencji, w jaki sposób będą one badane przez historię historiografii. Moim zdaniem pozostawanie w ramach wyznaczanych przez scjentyzm, nawet w jego miękkiej odmianie, z góry skazuje na niepowodzenie badania nie tylko nad historią akademicką, ale także pozaakademickimi formami reprezentacji przeszłości.

Nie zgadzam się także ze stwierdzeniem Stobieckiego o konieczności wyjściu historii historiografii poza dotychczasowy główny przedmiot swoich zainteresowań. Nie chodzi mi oczywiście o sedno tego stwierdzenia. Z postulatu Stobieckiego można jednak wysunąć wniosek, iż historia historiografii w ogóle nie była dotychczas zainteresowana badaniami nad pozaakademickimi formami relacji z przeszłością. Chciałbym tymczasem zwrócić uwagę na artykuł Jerzego Maternickiego Dorobek polskiej historii historiografii w ostatnim dwudziestoleciu $(1957-1977)^{6}$ podsumowujący badania z lat 60. i 70. Autor wskazuje, iż lata 70. to początek badań nad „historią żywą” i świadomością historyczną ${ }^{7}$. Ich zapowiedź znajduje zaś w wypowiedziach Mariana H. Serejskiego z początku lat 60. o kierunku rozwoju historii historiografii. Mówi w nich on o badaniu nienaukowych, półnaukowych wyobrażeń, poglądów pseudohistorycznych ${ }^{8}$.

Wydaje mi się, iż postulowane przez Stobieckiego poszerzenie przedmiotu badań historii historiografii już nastąpiło. Nie mam zamiaru jednak dyskutować z poglądem w tej sprawie. W tym momencie jest to dla mnie mało znaczącą kwestią, o którą nie ma co kruszyć kopii.

\footnotetext{
4 Zob. A. Szahaj, Postmodernizm a scjentyzm, [w:] Tenże, Zniewalająca moc kultury. Artykuly i szkice z filozofii kultury, poznania i polityki, Toruń 2004, s. 15-31.

5 W. Piasek, Metodologia historii i historia historiografii wobec kulturowej różnorodności, [w:] Oblicza przeszłości, red. W. Wrzosek, Bydgoszcz 2011, s. 323-335.

6 J. Maternicki, Dorobek polskiej historii historiografii w ostatnim dwudziestoleciu (1957-1977), [w:] Tenże, Kultura historyczna dawna i wspótczesna. Studia i szkice, Warszawa 1979, s. 333-404.

7 Tamże, s. 392.

8 Tamże, s. 339.
} 
Istotniejsza jest dla mnie, nie tyle odpowiedź historiograficzna na klasyczne historiograficzne pytania „kto badał?”, ,jaki rozmach te badania miały?”, ,czy stanowily one ilościowy margines prac z historii historiografii?" itp., ale jak takie badania byly prowadzone. Nie wystarczy bowiem śmielsze wejście historii historiografii na stary/ nowy teren badań. Zależy mi na zaproponowaniu nowych ram teoretycznych w jakich dziś takie badania mogłyby się rozwijać. Postulowane wyjście przez historię historiografii z ram dotychczasowych zainteresowań widzę jako zasadniczą zmianę w ujęciu pozaakademickich reprezentacji przeszłości i narzędzi ich badania.

Zanim przejdę do prezentacji swojej propozycji badań, przypomnę dyskusje, jakie toczyły się wokół pojęcia świadomości historycznej. Kategoria ta w latach 80. stosowana była na gruncie historii historiografii i metodologii historii do problematyki nieakademickich form relacji z przeszłością. W dyskusji wzięli udział badacze aktywni po dzień dzisiejszy. Przypomnę poglądy, które zostały wygłoszone na konferencji zorganizowanej przez Jerzego Maternickiego w 1985 r. oraz teoretyczne efekty badań specjalnego zespołu do badania świadomości historycznej kierowanego przez Jerzego Topolskiego powołanego w końcu lat 70. Wystąpienia i zapis dyskusji z konferencji ukazały się drukiem w pracy Świadomość historyczna jako przedmiot badań historycznych, socjologicznych $i$ historyczno-dydaktycznych ${ }^{9}$. Ustalenia zespołu zostały opublikowane w monografii pod redakcją J. Topolskiego Świadomość historyczna Polaków. Problemy $i$ metody badawcze ${ }^{10}$. W konferencji zorganizowanej przez J. Maternickiego wzięło udział 70 osób m.in. historyków, metodologów historii, historyków historiografii. W zespole Topolskiego pracował m.in. historyk historiografii A. F. Grabski.

$\mathrm{Na}$ wspomnianej już konferencji referaty wygłosili zarówno J. Maternicki, jak i J. Topolski. Traktuję ich jako przedstawicieli dwóch wzorów myślenia odnośnie świadomości historycznej. Prezentację ich poglądów zacznę od J. Topolskiego.

W publikacji pokonferencyjnejJ. Topolski opublikował artykuł Rola świadomości historycznej w procesie dziejowym ". Odwołam się jednak nie do tego wystąpienia, ale artykułu ze wspominanego tomu Świadomość historyczna Polaków. We wstępie i zamieszczonym artykule $O$ pojęciu świadomości historycznej Topolski szerzej niż w wystąpieniu konferencyjnym zaprezentowal poglądy na temat potrzeby badań nad świadomością historyczną ${ }^{12}$.

9 Świadomość historyczna jako przedmiot badań historycznych, socjologicznych i historyczno-dydaktycznych. Materialy konferencji naukowej, Warszawa 13 czerwca 1985, red. J. Maternicki, Warszawa 1985.

10 Świadomość historyczna Polaków. Problemy i metody badawcze, red. J. Topolski, Łódź 1981. Warto zwrócić uwagę na pracę: Spoteczna funkcja historii a wspótczesność, [w: ] Z. Mańkowski, J. Pomorski, Lublin 1985.

11 J. Topolski, Rola świadomości historycznej w procesie dziejowym, [w:] Świadomość historyczna jako przedmiot badań, s. 11-24.

12 J. Topolski, O pojęciu świadomości historycznej, [w:] Rola świadomości historycznej, s. 11-33. 
Świadomość historyczna jest według Topolskiego częścią struktury motywacyjnej działań indywidualnych i społecznych - świadomości społecznej. Stanowi składową proponowanych przez niego poglądów na proces dziejowy i w konsekwencji wzorzec naukowej historiografii według aktualnych standardów. Topolski przeciwstawia się ujmowaniu procesu dziejowego jedynie jako obiektywnego. Głosi niezbędność uwzględnienia subiektywnej strony dziejów w badaniach i historiografii, na którą składa się świadomość społeczna jako nie tylko jej aspektu, ale także czynnika wyjaśniającego.

$\mathrm{W}$ toku $[\ldots]$ rozważań teoretycznych - pisze Topolski - dochodzimy [...] do wniosku $[\ldots]$, że niemożliwe jest względnie pełne zrekonstruowanie procesu historycznego, a co ważniejsze - jego wyjaśnienie bez odwołania się do sfery świadomości ludzkiej. Postulat $[\ldots]$ jej badania wysuwa się jako jeden z podstawowych postulatów badawczych współczesnej historiografii ${ }^{13}$.

Rozważania Topolskiego toczą się na płaszczyźnie krytyki dotychczasowej historiografii określanej przez niego jako faktograficzna i przeciwstawianiu się dotychczasowym wzorcom badania przeszłości. Jego propozycja historii teoretyczno-wyjaśniającej to, w obszarze mnie interesującym, wspomniane uwzględnienie subiektywnej strony dziejów i jednoczesne przekroczenie potocznego doświadczenia historycznego w ujmowaniu tego aspektu dziejów charakterystyczne dla historiografii faktograficznej.

Świadomość historyczna według Topolskiego to „funkcjonujący w toku działania [... ] zasób wiedzy (szeroko pojętej tzn. nie tylko adekwatnej) i system ocen dotyczących przeszłości społeczeństwa (rodu, narodu, regionu, kontynentu, świata itd.) ${ }^{\prime 14}$. W innym miejscu Topolski doprecyzowuje, iż chodzi o wiedzę o dziejach tj. faktach historycznych i związkach między nimi oraz system wartości, czyli zbiór ocen wypływający z określonej wiedzy. Wiedza ta może być wiedzą potoczną lub wiedzą naukową ${ }^{15}$. Podkreśla on, że wiedza o przeszłości to również mity i legendy, a także dookreśla, co rozumie przez wiedzę potoczną. Obok własnego doświadczenia ludzi w jej skład wchodzą informacje uzyskane różnymi drogami od innych. Zdaniem Topolskiego przez długi czas najważniejsza była edukacja szkolna, której konkurentem obecnie są środki masowego przekazu: radio, telewizja i film ${ }^{16}$.

Jerzy Topolski zwraca uwagę, iż świadomość historyczna to pewien obszar kultury. Mówienie zatem i badanie świadomości historycznej to zarazem mówienie i badanie kultury. Świadomość historyczna to rezerwuar reguł interpretacji kulturowej oraz sensów kulturowych. Determinowanie działań przez świadomość historyczną

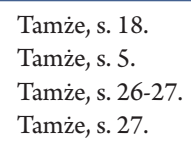


to nadawanie im przez społeczeństwo sensów kulturowych. Interesujące jest to, jak Topolski rozumie kulturę. Zwraca uwagę, iż przyjmuje szerokie jej rozumienie. Kultura to świadomość, sposoby działania i klasy rezultatów działania. Odrzucając wąskie rozumienie kultury nie tylko przeciwstawia się jej ograniczeniu do kultury symbolicznej, ale także wcześniejszemu utożsamianiu kultury z tzw. kulturą humanistyczną (życie artystyczne itd. $)^{17}$.

W swojej koncepcji badań nad świadomością historyczną Topolski szczególne znaczenie przywiązuje do bycia świadomym wpływu wiedzy o dziejach i związanego z nią systemu wartości (świadomości historycznej) na działania oraz adekwatności tej wiedzy z aktualną naukową wiedzą historyczną. W tym kontekście wyznacza relacje między świadomością historyczną a tradycją. Zdaniem Topolskiego świadomość historyczna jest pojęciem pojemniejszym niż tradycja historyczna. Wskazuje jednak, iż istnieją sytuacje, kiedy pokrywają się ze sobą. Są to, jak zaznacza, skrajne przypadki. Tradycja to według Topolskiego „wszystkie treści historyczne $[\ldots]$ które zostały społeczeństwu $[\ldots]$ przekazane przez poprzednie pokolenia za pomocą żywiołowego procesu utrwalania i zapominania” ${ }^{\text {"18 }}$. Kluczowa w rozróżnieniu tradycji od świadomości historycznej jest żywiołowość procesów jej przejmowania i zapominania. Wspomniane pokrywanie się świadomości historycznej i tradycji, zachodzi zdaniem Topolskiego, gdy występuje deficyt

$\mathrm{w}[\ldots]$ świadomości historycznej elementów dodatkowych i korygujących tradycję, refleksji niejako z oddalenia, spojrzenia krytycznego na własne dzieje itp. [...] tradycja historyczna jest żywiołowym, prymitywnym etapem rozwoju świadomości historycznej ${ }^{19}$.

W związku z powyższym świadomość historyczna ma dla Topolskiego dynamiczny charakter. Rozwija się i może być mniej czy bardziej rozbudowana, mniej lub bardziej „skorygowana” czyli naukowa. Idealna świadomość historyczna zawiera w sobie wiedzę prawdziwą, nie opartą, tak jak to ma miejsce w tradycji, na mitach i nieprawdzie. Jednocześnie jednak wskazuje, iż taka świadomość powinna być traktowana jako coś, do czego możemy się tylko zbliżaće ${ }^{20}$.

Posiadanie świadomości historycznej poddanej krytycznej weryfikacji powoduje, iż nie tylko jednostki, ale i społeczeństwo dysponują adekwatną wiedzą w podejmowaniu decyzji. Fakt, iż społeczeństwo do przekazanych treści i ich przejmowania oraz zapominania wykorzystuje wiedzę naukową oznacza, według Topolskiego, przede

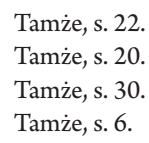


wszystkim zdawanie sobie sprawy z roli wiedzy o przeszłości (świadomości historycznej) w działaniu, i co za tym idzie, aktywny a nie bierny stosunek do przekazywanej wiedzy i ocen ${ }^{21}$. Postawę taką przeciwstawia sytuacji, kiedy to świadomość historyczna pokrywa się z tradycją. Wówczas to wiedza funkcjonuje w sposób mniej lub bardziej nieuświadamiany, „ciążąc” społeczeństwu ${ }^{22}$. W kształtowaniu się świadomości historycznej kluczową rolę odgrywa historiografia. Nie może to być jednak historiografia faktograficzna, która, jak wspominałem, nie jest w stanie, według Topolskiego, przekroczyć potocznego doświadczenia historycznego i korygować w świadomości potoczną wizję przeszłości.

Topolski proponuje, by badanie świadomości historycznej dotyczyło trzech zagadnień:

1) rekonstrukcji form i treści świadomości historycznej w różnych okresach i na różnych terytoriach; 2) wyjaśnienia tych form i treści, tzn. udzielenie odpowiedzi na pytanie, dlaczego badana świadomość historyczna rozwijała się w taki a nie inny sposób; 3) sposobu posługiwania się uzyskaną wiedzą o świadomości historycznej do wyjaśnienia działań ludzkich [...], kiedy to owa wiedza przybiera charakter części eksplanansu $[\ldots]^{23}$.

Dwa pierwsze punkty ściśle związane są z rekonstrukcją świadomości historycznej i budową całościowego obrazu przeszłości, obejmującego jej subiektywny i obiektywny aspekt. Ponadto znajomość świadomości historycznej niezbędna jest do przeprowadzenia wyjaśnień i uwzględnienia w nich subiektywnego aspektu dziejów. Jest to, jak pisze Topolski, „niejako dalszy etap badań nad świadomością historyczną: badanie jej społecznego funkcjonowania jako elementu struktury motywacyjnej”24. Kolejny etap to analiza genezy i czynników ją kształtujących. Topolski podkreśla, iż „wyjaśnienie świadomości historycznej można uznać za jeden z podstawowych postulatów historiografii nowoczesnej doby przełomu teoretycznego, tzn. takiej historiografii, która nie będzie jedynie uogólnieniem potocznego doświadczenia”25.

Zagadnienie badań nad świadomością historyczną jest u Topolskiego problemem funkcji wiedzy o przeszłości jako elementu struktury motywacyjnej. Obejmuje dwa powiązane aspekty z naciskiem na ten pierwszy: metateoretyczny i konkretnohistoryczny. Pierwszy dotyczy rozumienia procesu historycznego oraz praktyki wyjaśniania w historiografii - miejsca oraz kształtu subiektywnej strony dziejów jako struktury motywacyjnej. Drugi zawiera konkretno-historyczne analizy rekonstruujące świadomość historyczną, uwzględnienie w wyjaśnieniach badanych zagadnień

$\begin{array}{ll}21 & \text { Tamże. } \\ 22 & \text { Tamże. } \\ 23 & \text { Tamże, s. 7. } \\ 24 & \text { Tamże, s. 33 } \\ 25 & \text { Tamże. }\end{array}$


świadomości historycznej oraz wyjaśnienie jej samej. Na obydwu poziomach, tyle, że w różnych trybach, teoretycznym i konkretno-historycznym pojawiają się problem relacji między stanem świadomości historycznej a naukową wiedzą historyczną, jej relacja $\mathrm{z}$ tradycją.

J. Maternicki, w swoim artykule uznał, iż proponowane przez Topolskiego pojęcie świadomości historycznej jest „zbyt szerokim rozumieniem pojęcia”. Podkreśla, iż to co Topolski nazywa „świadomością historyczną” pokrywa się z pojęciem „myślenia historycznego" i jest mało przydatne w badaniach historiograficznych. Kluczowe dla niego jest rozróżnienie na historię „żywą” i „martwą”26.

Świadomość historyczna według Maternickiego składa się z wyobrażeń o przeszłości i związanych z nimi wartości. Obejmuje ona według niego jedynie wyobrażenia „żywe”. Należą do nich te, które łączą się bezpośrednio z aktualną sytuacją społeczną, wartościami i wizjami przeszłości jakiejś grupy ${ }^{27}$. Jak podkreśla Maternicki

chodzi zawsze o te jedynie treści historyczne, które stanowią „żywy składnik świadomości społecznej” wpływają na postawy społeczne i polityczne ludzi. Poza zakresem tak rozumianej świadomości historycznej pozostają treści mniej lub bardziej „obojętne”, a więc niemające większego znaczenia „praktycznego”. Jest to właśnie historia „martwa”, pozbawiona bezpośrednich odniesień do aktualnej sytuacji danej jednostki czy grupy społecznej ${ }^{28}$.

Tak rozumianą świadomość historyczną zdaniem Maternickiego należy odróżnić od wiedzy historycznej, z którą pozostaje w związku. Mają one zasadniczo odmienną strukturę ${ }^{29}$.

Świadomość historyczna [... ] składa się z różnorodnych składników, zarówno prawdziwych, jak i fałszywych. Jest to historia w dużym stopniu zmitologizowana, silnie przesiąknięta wartościującymi, o prostej skali ocen [...]. „Historia żywa” funkcjonuje w głównej mierze na zasadzie autorytetu, jest więc bardziej przedmiotem wiary niż dociekań. Charakteryzuje się też małą podatnością na argumenty racjonalne i stosunkowo dużą trwałością ${ }^{30}$.

Świadomości historycznej nie należy również utożsamiać z ideologią, która jest „wymyślona”, zazwyczaj przez wąską grupę osób. „Historia żywa” ma kształtować się naturalnie i żywiołowo. A w kształtowaniu jej uczestniczą niemal wszyscy członkowie określonej zbiorowości ${ }^{31}$.

26 J. Maternicki, Świadomość historyczna jako przedmiot badań historycznych, [w:] Świadomość historyczna jako przedmiot badań historycznych, s. 24.

27 Tamże, s. 26.

28 Tamże.

29 Tamże, s. 27.

30 Tamże.

31 Tamże, s. 29. 
Zdaniem Maternickiego świadomość historyczna ma wielowarstwową strukturę. Składają się na nią następujące warstwy: warstwa zewnętrzna, w skład której wchodzą wyobrażenia o konkretnych wydarzeniach i postaciach historycznych, warstwa sądów ogólnych, dotyczących całości dziejów własnej wspólnoty, które wyrażają system wartości danej grupy oraz warstwa historiozoficzna, która złożona jest z wyobrażeń o stawaniu się i mechanizmach dziejów ${ }^{32}$. Tak rozumiana świadomość historyczna stanowi

aktywny element przemian dziejowych $[\ldots]$ nie [jest] tylko odbiciem [świadomości społecznej - W. P.], ale także punktem wyjścia [...] „praprzyczyną" wielu poglądów, postaw i działań społecznych ${ }^{33}$.

Jerzy Maternicki proponuje trzy drogi badania świadomości historycznej na gruncie historii historiografii. Pierwszą jest analiza zachowania jednostek i grup. Jako przykład podaje kultywowanie określonej tradycji, przechowywanie pamiątek historycznych, opiekę nad konkretnymi zabytkami, świętowanie rocznic itp. ${ }^{34}$. Kolejna droga to analiza dokumentów osobistych, w których można znaleźć wspomnienia, opisy, refleksje na tematy historyczne, jak np. opisy pamiątek, miejsc historycznych itp. Ostatnia droga, której Maternicki nadaje szczególne znaczenie, to badania nad edukacją historyczną. Według niego pozostałe ze względu na ograniczoną ilość materiału do badań nie gwarantują pełnego odtworzenia świadomości historycznej. Badania nad edukacją to analiza „zawartości komunikatów historycznych, adresowanych do społeczeństwa (podręczników, powieści, wyobrażeń plastycznych itp.), jak też ich odbioru w różnych środowiskach społecznych"35. Maternicki podkreśla przy tym, że nie chodzi tu o odtworzenie wiedzy historycznej w ogóle, ale tych jej aspektów, które miały znaczenie „praktyczne”36.

Cel tak zaplanowanych badań nad świadomością historyczną, w sposób jednoznaczny przedstawia Maternicki w podsumowaniu swojego artykułu. Świadomość historyczna jako sprawczy czynnik dziejów

wplywa na programy spoleczne i ustrojowe, a także zachowania polityczne jednostek i grup społecznych. Bez dokładnego, wyczerpującego zbadania dziejów polskiej świadomości historycznej nie będziemy w stanie zrozumieć wielu doniosłych problemów naszego życia społecznego i politycznego ${ }^{37}$.

Na koniec rekonstrukcji poglądów J. Maternickiego na świadomość historyczną i jej badanie zacytuję fragment z podsumowującego konferencję i dyskusję artykułu. J. Maternicki pisze w nim: „Historycy historiografii nie zadawalają się już dziś śledzeniem

\footnotetext{
32 Tamże, s. 30.

33 Tamże.

34 Tamże, s. 30-31.

35 Tamże, s. 33.

36 Tamże, s. 35.

37 Tamże, s. 48.
} 
dziejów nauki historycznej i paranaukowego pisarstwa historycznego. Interesują ich także, i to w coraz większym zakresie, pozanaukowe formy myślenia historycznego, znajdującego swój wyraz nie tylko w sztuce, literaturze pięknej czy publicystyce, ale także w historiografii «oralnej», w mitach i legendach. Rozszerzeniu się zakresu zainteresowań badawczych nie towarzyszy, niestety, pogłębiona refleksja metodologiczna”38.

Różnice, które zostały ujawnione w dyskusji konferencyjnej nad referatami Topolskiego i Maternickiego odnośnie badań nad świadomością historyczną, według mnie mają drugoplanowe znaczenie. W kluczowej kwestii poglądy Topolskiego i Maternickiego oraz historyków na badania nieakademickich form relacji z przeszłością, tj. poglądu na historię akademicką i, szerzej, naukę są zbieżne. Program nowych badań wymaga zdystansowania się wobec nich ${ }^{39}$.

Obydwie propozycje zakładają szczególne znaczenie historiografii akademickiej w relacji z przeszłością. Dla obu badaczy wynika to z jej naukowego charakteru. Kluczowe znaczenie w zainteresowaniach pozaakademickimi formami relacji z przeszłością ma dla nich historiografia. Nie mnożąc problemów do omówienia, zadam tylko retoryczne pytanie, kiedy to historia akademicka odgrywała pierwszoplanową rolę w reprezentacji przeszłości? Stawianie historiografii na pierwszym miejscu oznacza nie tyle nawet ograniczenie $\mathrm{w}$ zainteresowaniu pozaakademickimi formami reprezentacji przeszłości, ale ich spłycenie. Nie tylko dokonuje się to poprzez umieszczenie tych zainteresowań w kontekście percepcji własnej praktyki badawczej i jej szczególnego uhonorowania. Przede wszystkim pozbawienie kulturowej autonomii nieakademickich reprezentacji przeszłości skutkuje rozpatrywaniem ich jako błędów w myśleniu, dowód na ignorancję społeczeństwa odnośnie ich historii.

Wydaje mi się, iż podobnie problem ten widziany jest we współczesnej historii historiografii. Nic się w tej kwestii zasadniczo nie zmieniło. Obecne zainteresowanie nieakademickimi relacjami z przeszłością powiela zainteresowania z lat 80 . Aktualny stan kultury przyczynił się jedynie do zdynamizowania tych zainteresowań. Podważenie wyjątkowości nauki w ogóle spowodowało otwarcie się szerzej na inne formy relacji z przeszłością. Reprodukują one jednak powyżej przedstawiony model zainteresowania nieakademickimi relacjami z przeszłością. Jest ono motywowane koniecznością reakcji na „zagrożenia” plynące $\mathrm{z}$ ich strony.

38 J. Maternicki, Kontrowersje wokót pojęcia świadomości historycznej i metod jej badania, [w:] Świadomość historyczna jako przedmiot badań, s. 225.

39 W dyskusji wzięli udział także socjolodzy. Trafnie z ich punktu widzenia dyskusję, kilkanaście lat później, podsumowała B. Szacka pisząc, iż starły się na konferencji dwa punkty widzenia: socjologiczny i scjentystycznohistoryczny. W tym pierwszym nie jest istotne w jakiej mierze to co się pamięta jest zgodne z tym co kiedyś było, nie ma w nim także zgody na to, iż postawy wobec przeszłości kształtowane są przede wszystkim przez historię akademicką. B. Szacka, Czas przeszły, pamięć i mit, Warszawa 2006, s. 23. 
Współczesna refleksja dotycząca nauki i myślenia naukowego powinno raczej skłonić do uznania, iż nieakademickie formy reprezentacji przeszłości są częścią odrębnego sposobu oswajania rzeczywistości. Stawianie ich w relacji do równie stanowiącej część kultury nauki, nie ma sensu. Takie jej ujęcie nie tylko nic nie wnosi do ich rozumienia, ale podtrzymuje także mało przekonujący sąd o specjalnym statusie samej historiografii.

$\mathrm{W}$ poszukiwaniu fundamentów dla propozycji odmiennego ujęcia i badania poza-akademickich form relacji z przeszłością proponuję zwrócić się do antropologii kultury. Od kilku lat staram się uprawiać etnografię myśli współczesnej w zakresie, czy też dziedzinie, historii. Fundamentem tych badań jest antropologicznie rozumiane pojęcie kultury w wariancie zaproponowanym przez C. Geertza. Jest ono traktowane przeze mnie niekanonicznie, łącze je m.in. $\mathrm{z}$ dorobkiem polskiego kulturoznawstwa J. Kmity a także Nowej Etnologii Polskiej. Świat historii akademickiej to dla antropologii nowy teren badań. Propozycja Geertza stanowiła wejście antropologii kultury na dotychczasowo nieeksploatowany teren myśli współczesnej, w tym naukowej. Pozwala ona na kulturowe ujęcie nauki w tym historii. Nie ma potrzeby charakteryzować tej propozycji. Szeroko na ten temat piszę gdzie indziej ${ }^{40}$. $\mathrm{Z}$ racji podjętego $\mathrm{w}$ tym artykule problemu bliżej przedstawię to jakie miejsce myśleniu naukowemu wyznacza Geertz w kulturze i ramach dotychczasowych zainteresowań myśleniem przez antropologię kultury. Moim zdaniem tradycyjny obszar jej badań w tym zakresie pozostaje w ścisłym związku z badaniami historii historiografii nad nieakademickimi reprezentacjami przeszłości. Dorobek antropologii powinien być w nich spożytkowany.

Clifford Geertz korzystając z metafory Ludwika Wittgensteina, porównuje kulturę do miasta. Składa się ono ze starej części, plątaniny uliczek i placów, starych i nowych domów, i nowej części, prostych i regularnych ulic, i standardowych domów. Antropologia według Geertza zajmowała się dotychczas „starym miastem”, dopiero ostatnio zaczęła się interesować „przedmieściami” ”1. Jako kryterium odróżnienia między społeczeństwami „pierwotnymi” a „współczesnymi” Geertz wskazuje obecność „przedmieść” na obrzeżach „starego miasta”, to, do jakiego: „na tej odziedziczonej mozaice przejętych praktyk, przyjętych wierzeń, zwyczajowych sądów i niekontrolowanych emocji narosły uładzone i uporządkowane systemy myśli i działania [podk. W. P.] - fizyka, kontrapunkt, egzystencjalizm, chrześcijaństwo, inżynieria, prawodawstwo, marksizm - które stały się tak istotną cechą naszego krajobrazu, że bez nich, bądź czegoś im podobnego, nie potrafimy wyobrazić sobie świata”"2. Wśród

40 W. Piasek, Historia jako wiedza lokalna. „Antropologiczne przesunięcie” w badaniach nad historiografią PRL, Toruń 2011 [Cz. I, Etnografia myśli historycznej w zakresie historii].

41 C. Geertz, Myśl potoczna jako system kulturowy, [w:] Tenże, Wiedza lokalna. Dalsze eseje z zakresu antropologii interpretatywnej, przeł. D. Wolska, Kraków 2005, s. 81. Zob.: L. Wittgenstein, Dociekania filozoficzne, Warszawa 2000, s. 16.

42 C. Geertz, Myśl potoczna, s 81. 
tych lepiej artykułowanych systemów symbolicznych znajdujemy naukową formę symbolicznego wyrażania, którą nie przez przypadek reprezentuje wymieniona na pierwszym miejscu fizyka, jakby nie było emblematycznie wiązana z nauką.

Dla Geertza różnica między „starym miastem” a „przedmieściami” to kwestia nie tyle prymitywizmu, ale jedynie odmienności w zorganizowaniu systemów symboli. A jedna z najstarszych dzielnic ludzkiej kultury (półprzedmieście), „niespecjalnie uporządkowana czy jednolita, ale ciągle dążąca poza labirynt małych uliczek i placyków ku mniej przypadkowemu kształtowi” jest myśl potoczna ${ }^{43}$.

Proponuję analogicznie, jak to miało w przypadku metodologii historii, tym razem etnografię myśli potocznej w dziedzinie nieakademickich form relacji z przeszłością. Myśl potoczna, wpółprzedmieście kultury, to według Geertza osobna sfera kultury, którą należy badać podobnie jak inne jej dziedziny. Składają się na nią interpretacje danych doświadczenia, a nie ich kopia. Mają one historyczny charakter i są kwestionowane, afirmowane, rozważane i rozwijane. Są różnorodne w ramach określonych większych społecznych całości. Nie są to także, jak to zazwyczaj się uważa, treści przyjęte spontanicznie tzn. „bez-myślne”. Geertz podkreśla, iż stanowią one jedynie względnie zorganizowaną strukturę myśli, różnią się od treści obecnych na przedmieściach np. od nauki poziomem systematyzacji ${ }^{44}$. Nauka opiera się na metodzie, a zdrowy rozsądek nie potrzebuje żadnych dowodów ${ }^{45}$.

Jak trafnie podsumowuje poglądy Geertza na myśl potoczną Dariusz Czaja, w ujęciu Geertza jest to wiedza, jak każda inna, tyle że szczególnego rodzaju,

nie jest ani „gorsza”, ani bardziej „prymitywna” niż poznanie naukowe. To zupełnie inna sfera myślowego oswajania rzeczywistości, stąd porównywanie jej z wiedzą „prawdziwą”, resp. naukową, nie mają większego sensu, nie wnoszą też nic do rozumienia jej specyfiki. Inaczej jeszcze rzecz ujmując: jest to po prostu wiedza całkowicie adekwatna do życiowych i egzystencjalnych potrzeb, które zaspakaja ${ }^{46}$.

D. Czaja zwraca uwagę na podobieństwo kategorii myślenia potocznego do wykładni mitu i mitologii Rolanda Barthesa. Zostawmy na uboczu polityczny wymiar poglądów Barthesa na mit i jego obecność w kulturze współczesnej. Ważny jest wniosek, jaki Czaja wysuwa. Stwierdza on, iż mit „okazuje się [... ] w tym ujęciu niemalże innym imieniem potoczności”' ${ }^{37}$. Obok myślenia potocznego w słowniku teoretycznym historyka historiografii badającego pozaakademickie relacje z przeszłością powinny znaleźć się kategorie mitu, myślenia mitycznego i mityzacji - reguły mitycznego sposobu percepcji

43 Tamże, s. 85 .

44 Tamże, s. 82.

45 Tamże, s. 83.

46 D. Czaja, Anatomia duszy. Figury wyobraźni i gry językowej, Kraków 2005, s. 172. Na temat myśli potocznej zob. także: T. Hołówka, Myśl potoczna. Heterogeniczność zdrowego rozsądku, Warszawa 1986; Kategoria potoczności. Źródła filozoficzne i zastosowania teoretyczne, red. A. Jawłowska, Warszawa 1971.

47 Tamże, s. 171. 
rzeczywistości. Nie są to nieznane narzędzia analizy i interpretacji w historii historiografii. Mit i myślenie mityczne są jednak rozumiane przez tych badaczy w kontekście następstwa czasowego „prymitywne” i „nowoczesne-naukowe” ze wszystkimi konsekwencjami ${ }^{48}$. Kolejną kategorią, którą posłuży się etnografia pozaakademickich form relacji z przeszłością, jest kultura popularna. Antropologia, zgodnie ze swoim niewartościującym podejściem do kultury i jej badania, traktuje ją jak każdy inny aspekt kultury, który warto zbadać, chcąc zrozumieć innego człowieka. Co ważne, istotnym jej wyznacznikiem jest wyrażanie codziennych doświadczeń. Stanowi kulturową formę, w jakiej codzienność jest praktykowana. Jak podkreśla teoretyk i badacz kultury popularnej Marek Krajewski, w ujęciu antropologicznym „kultura popularna to ten rodzaj kultury, który najbliższy jest codzienności, naszym najbardziej prozaicznym zajęciom" ${ }^{49}$.

Scharakteryzowane powyżej pokrótce kategorie tworzą teoretyczne zaplecze etnografii nieakademickich relacji z przeszłością. Nie jest ono, jak mogłoby się wydawać składem różnych kategorii. Kategorie te tworzą teoretyczną całość określającą kierunek analiz. Myśl potoczna to forma ludzkiej dyspozycji intelektualnej, mit i „logika mitu” organizują operacje symboliczne, jakie dokonują się w myśleniu potocznym, kultura popularna to aspekt i zarazem typ kultury, w którym wyrażana jest myśl potoczna.

Proponuję, by historia historiografii, tak jak antropologia, która wychodząc poza swoje klasyczne zainteresowania, zajęła się myślą naukową, tak historia historiografii, wychodząc poza dotychczasowy krąg swoich zainteresowań, zajęła się myślą potoczną. Niegdyś klasycznym przedmiotem zainteresowań antropologii kultury. Historia historiografii zawężałaby tę problematykę do relacji z przeszłością. Ważniejsze od kwestii wyznaczenia granic jest jednak wykorzystanie przez nią dorobku teoretycznego, jaki ma antropologia w badaniu myśli potocznej w ogóle. Co oczywiste, nie można także pomijać konkretnych jej badań nad nieakademickimi formami relacji z przeszłością, które również są w niej prowadzone. Istotne miejsce w słowniku teoretycznym etnograficznej historii historiografii powinny zająć, obok myśli potocznej, także kategorie mitu oraz kultury popularnej ${ }^{50}$.

48 Doskonale te konsekwencje przedstawione zostały przez Czesława Robotyckiego w kontekście relacji między historią a tradycją. Zob.: Cz. Robotycki, Etnografia wobec kultury wspótczesnej, Kraków 1992, s. 29-65. Zob. także: J. Niżnik, Symbole a adaptacja kulturowa, Warszawa 1985.

49 M. Krajewski, Kultury kultury popularnej, Poznań 2003, s. 31. Zob. także: J. Barański, Etnologia i okolice. Eseje antyperyferyjne, Kraków 2010, [rozdz. Rola antropologii w badaniach kultury popularnej i tożsamości]. Barański, przedstawiając kontrowersje wokół rozumienia kultury popularnej zwraca uwagę, iż możną ją rozumieć w kategoriach „dawniejszej kultury ludowej”. Tamże, s. 155. Moim zdaniem w tym kierunku szła propozycja Cz. Robotyckiego badania przez etnografię kultury współczesnej. Jak pisał: „ludowy to dzisiaj pewien typ reakcji kulturowej, a nie funkcja miejsca zamieszkania. [...] uważam, że etnografia może się zmierzyć z kulturą współczesną, jeśli podejmie się interpretacji odkrywających mityczne zorganizowanie kultury”. Cz. Robotycki, Etnografia, s. 9.

50 Pierwszą, wstępną, próbą praktycznej realizacji tych teoretycznych założeń jest artykuł: W. Piasek, Historia poza akademią. Przeszłość w przemysłach kreatywnych, [w:] Między nauką a sztuką - wokót problemów wspótczesnej historiografii [w druku]. 